\title{
The Role of YouTube Media as a Means to Optimize Early Childhood Cognitive Development
}

\author{
Dwi Asmiarti ${ }^{1}$ and Guntur Winangun ${ }^{2}$ \\ ${ }^{1}$ Universitas Negeri Semarang, Indonesia \\ ${ }^{2}$ Universitas PGRI Semarang, Indonesia
}

\begin{abstract}
Early childhood cognitive development is formed faster in the first four years of life. YouTube as a video-based application media is used as a means to optimize children's cognitive development by some parents. The objective of this study was to determine the role of YouTube media in optimizing cognitive development in early childhood. The method used is qualitative with a phenomenological approach. Data collection techniques in this study were interviews and observations to parents of YouTube media users as a means of optimizing a more optimal development in aspects of imagination, language, curiosity, and concentration. Thus it can be concluded that YouTube media can be used as a means to optimize cognitive development in early childhood.
\end{abstract}

\section{Keywords: early childhood, YouTube media, cognitive development}

\section{Introduction}

Children's cognitive development shows the development of children's thinking. Cognitive development is the basis of a child's ability to think. This is appropriate with the opinion of Ahmad Susanto (2011: 48) that cognitive is a process of thinking, namely the ability of individuals to connect, assess, and consider an event. So cognitive processes are related to the level of intelligence that marks a person with various interests, especially aimed at learning ideas. Cognitive development has an important role for success children in learning because some activities in learning are always related to thinking problems.

Cognitive development is an emerging and rapidly developing aspect of the first four years of life. At this age, there will be many parts of the brain cortex that produce excess synapses as an initial implication of the child's development of interacting with the surrounding environment (Berk, 2012). Early age so-called golden age because of the physical and motor development of children thrive and grow rapidly both the development of emotional, intellectual, moral and even language character. For that, as parents, we should be able to provide the appropriate stimulation to help the development of cognitive children and not to miss the golden age passed by. There are factors that influence this development. Factors that influence cognitive development according to Piaget in Siti Partini (2003: 4) that "experiences derived from the environment and maturity both influence children's cognitive development". Meanwhile, according to Soemiarti and Patmonodewo (2003: 20), cognitive development is influenced by the growth of brain cells and the development of relationships between brain cells. The health and nutrition conditions of the child although still in the mother's womb will affect the growth and development of the child. According to Piaget in Asri Budiningsih (2005: 35) the more a person ages, the more complex his nerve cells are and the more he is able to improve. When an individual develops to maturity will experience a biological adaptation to the environment that will lead to qualitative changes in cognitive structure. There is another opinion that states that many factors can influence cognitive development. According to Ahmad Susanto (2011: 59-60) factors that can influence cognitive development such as: factors of heredity or descent, environmental, maturity, formation, interest and freedom.

YouTube is a service from Google that facilitates its users to upload videos and can be accessed by other users around the world for free. The availability of diverse video content also specifically for children, makes researchers interested in researching how the impact of YouTube media on children's intelligence related to the phenomenon of parents who provide video shows from YouTube to optimize cognitive development for their children. 
As an important note, the most fundamental thing when discussing early childhood development cannot be separated from the role of parents. In this study, parents have a very decisive role in optimizing the effectiveness of using YouTube media in optimizing early childhood cognitive development.

\section{Basic Theory}

\subsection{Cognitive Development}

According to Ernawulan Syaodih and Mubair Agustin (2008: 20), cognitive development concerns the development of thinking and how thinking activities work. In his life, maybe children are faced with problems that require solutions. Resolving a problem is a more complex step self-child. Before the child is able to solve the problem the child needs to have the ability to find a solution. Husdarta and Nurlan (2010: 169) argue that development Cognitive is a continuous process, but the results are not connection (continuation) of the results previously achieved. These results differ qualitatively between one and the other. Children will pass through stages of cognitive development or period of development. Every period of development, the child tries to find a balance between cognitive structure and experiences new. Imbalance requires new accommodation as well as the transformation of the next period. Based on some of the opinions above it was concluded that the factors cognitive have an important role for children's success in learning because most of the activities in learning are always related to the problem of remembering and thinking. Cognitive development is intended so children are able to explore the surrounding world through his five senses so that with the knowledge he got the child can live his life.

Piaget in Allen (2010: 29) states that cognitive development is a process of ongoing interaction between children and their perceptual views of an object or event in an environment. Cognitive development theory is developed by Jean Piaget, a Switzerland psychologist who lives in the years $1896-1980$. The theory provides many key concepts in the field developmental psychology and influences the development of the concept intelligence, which for Piaget, means the ability to more accurately represent the world and perform logical operations in concept representations based on reality. This theory discusses the emergence and acquisition schemata the scheme of how a person perceives his environment in the stages of development when someone acquires a new way of representing information mentally. This theory is classified into constructivism, which means, unlike theory nativism (which describes cognitive development as the appearance of innate knowledge and abilities), this theory argues that we build our cognitive abilities through motivated actions by itself to the environment. For the development of this theory, Piaget obtained the Erasmus Prize. Piaget divided the scheme used child to understand the world through four main periods that are correlated and increasingly sophisticated as growth increases age : Sensorimotor period (age 0-2 years), preoperational period (age 2-7 years), concrete operational period (age 7-11 years) and formal operational period (age 11 years to adult) .

\subsection{YouTube Media}

Basically, youtube is a website which facilitates users to share videos they have or limited to enjoying various video clips uploaded by various parties. There are various kinds of videos that can be uploaded to this site, such as music video clips from certain musicians, short films, television films, movie trailers, educational videos, vlogger video blogs, various video tutorials, and many more.

YouTube itself was established in February 2005. Youtube headquarters is in San Bruno, California, the United States initiated by three Youtube founders, namely Chad Hurley, Steven Chen, and Jawed Karim. The website which now contains billions of videos is growing very rapidly from the first time it was founded. In 2006 in November, even Google bought Youtube at a price of US \$ 1.65 billion.

YouTube earns income from advertisements displayed before youtube videos are played. The ad is named with Google AdSense, a program that offers payments based on the frequency level of a video played. In February 2017, it was noted that there were videos with a total duration of 400 hours uploaded on Youtube every minute and a total of one billion hours of Youtube content watched by people every day.

\subsection{Early Childhood}

Hurlock (Desmita: 2013) explains that childhood begins after a dependent baby, that is, around the age of 2 years until the child is sexually mature, ie 13 years old for women and 14 years for men. Early childhood is a child aged 0-8 years. According to Beichler and Snowman (Dwi Yulianti, 2010: 7), early childhood is children between 3-6 years old. Where as the nature of early childhood (Augusta, 2012) is a unique individual where he has a pattern growth and development in physical, cognitive, socio-emotional aspects, creativity, language and special communication that are in accordance with the stages that are being passed by the child. From the various definition, researchers conclude that early childhood is a child aged 0-8 years who are in the stage of growth and development, both physical and mental. Early childhood is often referred to as the " golden age ". At this time almost all of the potential children experience sensitive times to grow and develop quickly and superbly. The development of each child is not the same because every individual has different developments. Nutritious and balanced food and 
intensive stimulation are needed for growth and these developments. If the child is given intensive stimulation from the environment, the child will be able to carry out the task of good development.

\section{Research Methods}

\subsection{Research Approach}

The method used in this research is qualitative research with short or phenomenology. Sugiyono (2010:14) states that qualitative research methods are often referred to as naturalistic methods because their research is carried out under natural conditions ( natural setting) is also called the ethnographic method because it is on initially this method was more widely used for research in the field of cultural anthropology. The term phenomenology is often used as a general assumption to refer to subjective experiences of various types and types of subjects encountered. (Moleong, 2009: 15).

\subsection{Research Focus}

This study focused on how cognitive development in early childhood is stimulated using YouTube media by parents.

\subsection{Research Subjects}

The first subject was named Syafa Azika M aihusnah, 3 years old, the address is in the Tanggel Village, Winong District, Pati regency. The second subject was Velly Arlita Ahmad aged 2.5 years, the home address of Winong Village, Winong District, Pati regency, and the third subject was Arra, 2 years old, address of Tanggel Village, Winong District, Pati Regency.

\subsection{Data Collection}

Data collection methods carried out in this study were by interview and observation. The type of interview used is an unstandardized interview. Satori (2007) explains that open interviews are free interviews where researchers use interview guidelines in a formal context to collect data. While the observation used is non-participant observation. According to Sugiyono (2011), nonparticipant observation is an observation in conducting research researchers are not involved and only as independent observers.

\subsection{Data Analysis Technique}

The data analysis technique used in this study is a descriptor that contains a systematic and factual description. According to Moleong (2007), this analysis is carried out in three ways, namely: a ). Data reduction, namely the process of selection, concentration, research through a rigorous selection of the focus studied, b). Exposure or data presentation, namely the process of formulating complex formations in a systematic form so that they become more simple and selective and can be understood by their meaning, c). Conclusions, namely: the last step the researcher carried out in analyzing the data continuously both at the time of data collection or after data collection. 


\section{Results And Discussion}

\subsection{Research Result}

Following is the data table used in the study:

Tabel 1 data table used in the study

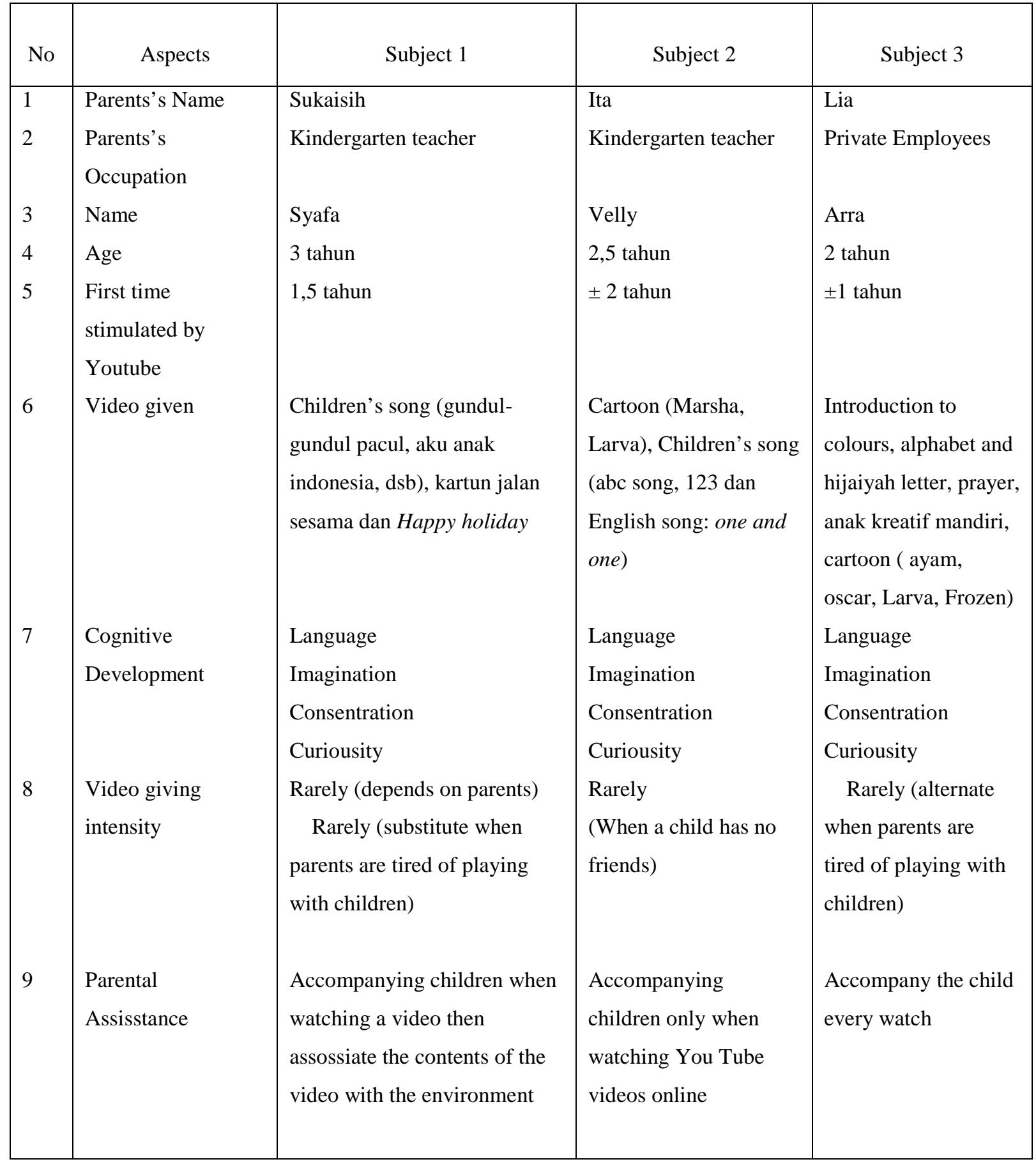




\subsection{Child Development}

\subsubsection{Language}

From the results of interviews and observations that have been made, found the development of language in children, as follows:

In subject 1 parents stated that in their 2 years old children are able to do two-way communication with other people, children also master some English words like " how do you do " and some numbers in English. The child also memorizes some traditional song such as Gundul-gundul Pacul and Indonesian children's songs.

In subject 2 children can say a few words in English such as words: eyes and colours.

In subjects 3 children are able to recognize colors, some letters of the alphabet and letters hijaiyah, memorize the prayers of starting to eat, after eating, going to sleep and waking up, children can begin to imitate what is seen and heard.

\subsubsection{Imagination}

From the results of interviews and observations that have been made, found the development of children's imagination as follows:

In subject 1, imagination develops well. She can think of himself as a figure of the cartoon he watches, she considers the strokes she makes as perfect images. Children can imagine using a pencil like a plane that is flying, the seat is like a car, the tablecloth is used to play baronsai.

In subject 2, the child's imagination develops quite well. Children chat with dolls. She considers inanimate things as if life has feelings.

In subject 3, the child's imagination develops quite well. The child wants to be like Frozen. He also draws people who are likened to her father, mother, and brother. Children imagine making milk by stirring empty glasses.

\subsubsection{Curiosity}

From the results of interviews and observations that have been made, found the development of Curiosity in children.

In subject 1 , when the child watches the video she always asks. Like when Tantan is sad, she asks his mother "Mommy, why is Tantan crying?", When Bob wrote the train, he asked, "What writing is it, Mrs.?", The child often asks about the surrounding objects that are similar to what he saw in the video.

In subject 2, curiosity is not much different from the subject 1 . The curiosity of a child is dominated by referring only to what he watches. Like "Why can Marsha get sick?", "Where do you take the train?"

In subject 3 the child's curiosity cannot be suppressed, in contrast to the first and second subjects, which have not led to curiosity.

\subsubsection{Concentration}

From the results of interviews and observations that have been made, the concentration of 1,2,3 subjects is relatively the same. Her concentration is seen when the child is watching videos online on mobile phones, he is focused on what he is doing.

\subsubsection{The Role of Parents}

In Subject 1, parents play an active role in accompanying children when watching a video and then linking the contents of the video to the environment. In the sense of implementing content with what is around and experienced by children. Parents also give colored books and show the colors in the video. In the street cartoon show, fellow parents gave examples of moral values in cartoon characters.

In subject 2, parents only play an active role when children watch YouTube videos, when in online mode. Sometimes children are left watching alone specifically on videos that have been downloaded by themselves and chosen by parents.

In subject 3, parents play an active role in accompanying children when watching YouTube videos. In this case, YouTube videos are only used by parents as a substitute for learning to help children's learning when parents are troubled or tired. 


\subsection{Discussion}

Based on the comparison of the subjects the results of the study explained that the children of the three subjects showed cognitive development in the area of imagination, language, curiosity, and concentration. Referring to the tables of YouTube video shows given from the three subjects included in the category of cartoons and music for children.

The most prominent and rapidly growing in YouTube video stimulation for the three subjects are in terms of language and imagination. This relates to the age of the three subjects who are in the stage of imitating the environment so that the stimulation of YouTube videos is based on English, songs, and prayer can be recorded by children in their memory well. From subjects 1 and 2 indicate a developmental tendency for color recognition. So in line with Kuriniawati's findings (2013) that audiovisual stimulation of video is able to help optimize cognitive development in color recognition more effectively in early childhood. While the findings in the child's imagination area, the interesting thing is the way children interpret their environment according to the imagination of what is contained in the video given. This concept is the same as the development of egocentrism in children which is marked by perceiving the outside world according to their will. Child behavior that is active here can be said to be the potential for kinesthetic intelligence that will develop in the child.

Furthermore, regarding the role of parents in providing stimulation, all three have a rare intensity and can assist in the stimulation process for each of their children. This implies that video stimulation is not the main thing given by parents to help optimize children's cognitive development. Parents of the three subjects stated that gadget, especially for video, is not the only stimulation that parents take preventively. This is to prevent addiction or the negative impact of using gadget. Parents also provide plenty of space for children to socialize with peers so that they can explore the environment.

\section{Conclusion}

In this study, it can be concluded that stimulation with YouTube videos can be used as a means to optimize early childhood cognitive development. This finding basically correlates audio-visual based learning in schools by recognizing media objects with YouTube. The results of the study illustrate that children who are given stimulation have a similar effect to previous studies. This can be a contributing method for developing early childhood cognitive development in the development of gadget technology and current social media.
Early childhood is a golden age where brain cell growth as an area of cognitive potential begins to develop rapidly when properly stimulated will have a positive impact on future development. Therefore stimulation of the YouTube video can be used as a reference for parents at home to develop children's intelligence to be more efficient and practical with this stimulation note carried out with appropriate guidance and guidance by parents.

\section{Suggestion}

\section{For the Society}

Due to the development of technology that facilitates access to all kinds of needs, this research is expected to provide an overview for the community about the positive scientific impact of psychology in developing early childhood cognitive use YouTube media with proper guidance and guidance by parents.

\section{For Further Research}

It is hoped that there will be further research that uses a qualitative and quantitative approach simultaneously to obtain a more comprehensive picture of early childhood cognitive development.

\section{References}

1. Berk , Laura E Development Though The Lifespan (edisi kelima). Terj. Darmanto, Yogyakarta: Pustaka Pelajar, 2012).

2. Brad \& Debra Scheep, How to Make Money With You Tube. New York: McGraw-Hill Education (2009).

3. Departemen Kesehatan Republik Indonesia Pedoman Deteksi Dini Tumbuh Kembang Balita, Departemen Kesehatan Republik Indonesia (2006).

4. Desmita Psikologi Perkembangan, Bandung :Remaja Rosdyakarya Offset (2013).

5. Fadillah Muhammad Desain Pembelajaran PAUD, Tinjauan Teoritik dan Praktik Yogyakarta: Ar-Ruzz media (2012).

6. Fort, mathilde Audio Visual Vowel Monitoring and the Word Superiority Effect in Chidren International Journal of Behafioral Development. (2012). 
7. Hanisah. Meningkatkan Kecerdasan Intrapersonal Anak Melalui Kegiatan Bercerita Berbantuan Media Film NCD dikelompok B5 RA Ummat An Wahidah di Kota Curup. Skripsi kependidikan Bagi Guru, Universitas Bengkulu. ,(2014)

8. Jahja, Yudrik Psikologi Perkembangan, Jakarta: Kencana (2011).

9. Kurniawati, Ita. Pengaruh Media Audio Visual pencampuran Warna terhadap Kemampuan Kognitif pada Anak Kelompok A TK My Children Kee. Candi Kabupaten Sidoarjo. (2013
10. Syaodih Mubiar Agustin, Ernawulan Bimbingan Konseling Untuk Anak Usia Dini, Jakarta: UT (2011).

11. https://www.nesabamedia.com/pengertianyoutube/ Pengertian Youtube Beserta Manfaat dan Fitur-fitur Youtube yang Perlu Anda Ketahui 